\title{
The Philosophical Polemics with the Vatsiputriyas About the Self (Pudgala) in "Tattvasamgraha" of Shantarakshita with the Commentary "Panjika" of Kamalashila*
}

\author{
Lev Titlin \\ RAS Institute of Philosophy \\ Peoples' Friendship University of Russia \\ 6 Miklukho-Maklaya Str. \\ Moscow, Russia \\ E-mail: titlus@gmail.com
}

\begin{abstract}
The article considers the philosophical polemics about the self (the pudgala) between "orthodox" Buddhism in the person of Shantarakshita and his direct disciple Kamalashila (8th century) with the "heretical" Buddhist school Vatsiputriya on the material of the chapter "The study of Atman by the Teaching of Vatsiputriyas" (Vatsiputriyaparikalpitatmapariksha) of the section "Atmapariksha" of "Tattvasamgrahapanjika". At the beginning of the article, a brief information on Shantarakshita and his work is given, as well as about Vatsiputriya. According to this school, the pudgala is the actor of karma, the enjoyer of its fruits, the subject of rebirth and experience. The author makes a conclusion about dissimilarity of the philosophical logics of the opponents.
\end{abstract}

Keywords-Shantarakshita; pudgala; self; no-self; anatman

"Tattvasamgraha"; atman;

\section{INTRODUCTION}

Santarakșita (8th century) ${ }^{1}$ (the name in one of the interpretations is Sāntirakșita, which is translated as the guardian of peace (śānti) - one of the outstanding thinkers of Ancient India, representative of the philosophical school of Yogācāra-svātantrika-madhyamaka ${ }^{2}$. He was a rector of the famous monastery-university of Nālandā, an enlightener of Tibet, was awarded the title of ācārya-bodhisattva ("bodhisattva-teacher") in Tibet, and many of his works were included in the Tibetan Buddhist canon "Tengyur." He is the author of numerous Mahāyāna works on Madhyamaka, Tantra, epistemology, Buddhist logic, author of tantric hymns and commentaries on tantric writings. But the most

* The work was carried out within the framework of the grant of the RSF No 16-18-10427 "Indian Philosophy in the Context of the History of World Philosophy: The Problem of the Translation of Meanings".

[3].

For more on Śāntarakṣita please see the article and books [1] [2]

For more on Yogācāra and Madhyamaka please see the articles and books [4] [5] [6] [7] [8]. famous work of Sāntarakșita is the monumental "Encyclopedia of Philosophical Problems" "Tattvasamgraha", consisting of 26 chapters (in the Tibetan translation of 31 chapters), in which 20 classical concepts of ancient Indian philosophy are consistently dealt and the teachings of the major schools of ancient India such as Vaiśeșika, Nyāya, Vedānta, Mīmāṃsā, Sāṃkhya, Yoga, Buddhism, Jainism and other schools (in particular, Vātsīputrīya, which will be discussed in this article) are refuted. One of the main values of the work is that Śantarakșita cites many of the statements and arguments of philosophers which would otherwise have been irretrievably lost, and his immediate disciple and commentator Kamalaśîla (8th century) in his commentary "Pañjikā" even quotes from their writings.

"Tattvasamgraha", for long considered irreversibly lost in its Sanskrit original, was published twice: by E. Kṛṣnāmācārya and S.D. Sāastrī [9] [10]. In English there is a unique translation of $\mathrm{G}$. Jha [11]. In addition, separately "Discussion with the Mīmāṃsakas on Ātman" was published, translated and explored by I. Ratié [12].

The text can be conditionally divided into three sections: ontological, epistemological and soteriological. The critique of the conceptions of the self that interests us belongs to the ontological section, namely, the chapter "Ātmaparīksā". In "Ātmaparīkșā", the doctrines of the self of the NyāyaVaiśeșikas, the Mīmāṃsakas, the Sāṃkhyas, the Jainas, the Vedāntists and the Vātsīputrīayas are examined and refuted. We have already examined and translated into Russian the chapters devoted to Nyāya-Vaiśeșika and Mīmāṃsā: a detailed study of the discussion with the Sāmkhyas will be published in the article [13] [14] [15]. The translation of Sāntarakșita's discussion with the Sāṃkhyas will be published in the publication [16]. 


\section{PUDGALAVĀDA}

In the section of "Ātmaparīkșā" under examination ("The Study of the Ātman, how it is Determined in Vātsīputrīya», "Vatsīputrīyaparikalpitātmāparīkșā̄") Śāntarakṣita tries to refute the doctrine of the pudgala of the Vātsīputrīyas, otherwise known as the Pudgalavādins (literary "The ones who teach about the pudgala). Under the pudgala the "quasisubject" or analogue of Brahmanist attman is understood, which is should explain the numerous contradictions in Buddhist teachings, such as who is the subject of rebirth, karma, enjoying the fruits of deeds, how cognition, perception, etc. are possible. As suggested by A. Bareau, Pudgalavāda there was a split among the Sthaviravādins (the future Theravādins), which occurred approx. [17]. 280 BC. By the 7th century Pudgalavāda acquires unprecedented popularity and becomes the most numerous of Buddhist communities. For more on Pudgalavāda please see the book by L. Priestley, our articles and also articles by V.G. Lysenko and V.K. Shokhin in [18] [19] [20] [21] [22].

The Vātsīputrīyas, who call themselves Buddhists, substitute "the pudgala" for the atman, and believe that it is neither different nor identical with the skandhas ${ }^{3}$. Although they call themselves the Saugatas, i.e. descendants of the Buddha (the Sugata, literary "the one who came well"), but under the name of pudgala, they teach the doctrine of the attman. Kamalaśila poses the question of how people who call themselves descendants of the Buddha who taught about anātman surrendered to the false doctrine of ātman. Therefore, Śāntarakșita calls them "those who view themselves as the Buddhists."

According to Kamalaśîla, the Vātsīputrīyas attribute to the pudgala the following properties: 1) it is an actor (kartr) of various good and bad deeds 2) it is enjoyer of pleasant and unpleasant fruits of deeds 3) it leaves the previous skandhas and assumes the new 4) it is the subject of experience 5) it is the ātman.

\section{THE PUdGala AS INEFFABLE}

Kamalaśîla asks what is the reason that the pudgala is called ineffable (avaktavya, i.e. not identical and not different from the skandhas)? To this, Śāntarakșita replies that if the pudgala were regarded as distinct from the skandhas, then the teachings of the Pudgalavādins would not be different from the teachings of the Tīrthhikas (the Brahmanists who teach about the existence of attman), which automatically would mean recognizing the doctrine of the eternal Ātman, but the eternal Ātman cannot be an actor and an enjoyer, as Sāntarakșita showed in the section of "Ātmaparīkșā" on the discussion with the Advaitists ${ }^{4}$, because such an Ātman would be undefined, like ākāśa

\footnotetext{
3 Buddhism divides all empiric phenomena, apart from the socalled asamskrta dharmas (to which belong the two types of cessation, or nirvana and ākāśa, empty space), into the 5 groups-skandhas (rūpa-skandha, or matter of sensuality, vedana-skandha, or feeling, samjñ̄ā, or representation, saṃskāra - karmic imprints and vijñāna - consciousness). In Advaita-vedānta, the ātman is considered to be pure consciousness (caitanya) outside the psyche, free from activity and enjoying the fruits of deeds.
}

(empty space, which is the place of manifestation of empirical phenomena). However, the Buddha, according to Kamalaśíla, denied the existence of the eternal Ātman, saying that "all dharmas are deprived of self" "(nirātmānah sarve dharmāh). If the pudgala is considered to be identical with the skandhas, such as rūpa ${ }^{5}$, then it will not be united, but multiple "and so on." However, the Pudgalavādins consider it as united, as when it is said "the pudgala is united, and is born in the world as united, and so is also the Tathāgata ${ }^{6} . "$ Kamalaśíla comments that the words "and so on" include non-eternality and other properties of non-eternal objects. Either way, in this case the pudgala would be liable to destruction, like the skandhas. Therefore, the Pudgalavādins prefer to call it ineffable (as it can be named neither identical, nor different from the skandhas).

\section{Why the PUdGala DoEs Not EXIST AS A REALITY?}

There is a problem here, says Sāntarakșita. If the pudgala is ineffable, then it cannot be said that it is exists as a reality (vastuvat), because, according to Buddhist theory, every real thing (vastu) can be expressed either as identical with another reality or as different. To the ineffable things belong such as "sky lotus" and other unreal things. Moreover, the Buddhists, deny, according to their logic, that a reality can be neither identical, nor different from another reality, because there is no other alternative, except that it is completely devoid of being and nature (nīrūpamasvabhāva). If this were not so, then rūpa-skandha could be called neither different nor identical with other real things, but this is not so, Kamalaśīla comments.

Śāntarakșita notes that only real things must be either distinct or non-different from each other, and those deprived of being avoid this alternative. Because when it is said that a thing is not the other thing, they are necessarily different, and when it is said that a thing is not what the other thing is not, they are identical.

The opponents ask the question, why is not the third alternative possible for real things? Kamalaśîla replies that if it is denied that the pudgala is identical with rūpa and other skandhas, then their difference is indicated, because the negation of identity is the necessity for the assertion of difference. If one reality is deprived of the properties of the other reality, as the rūpa-skandha is deprived of the properties of vedana-skandha, then they are necessarily different. The same is about the pudgala, if it is deprived of the properties of rūpa-skandha and other skandhas, then it is different from them. In the opposite situation, for example, when the property of being different from itself is denied with respect to rūpa-skandha, it is said that it is identical with itself. With regard to the pudgala, it is denied that it is not different from the skandhas, therefore, it must be identical with them.

All this is based on the nature of things. Therefore, says Kamalaśîla, no real thing can escape the alternative of being

\footnotetext{
G. Jha incorrectly translates the term rūpa as "color".

The Tathāgata is literary translated as "the one who came so" or "the one who went so," and is one of the epithets of the Buddha.
} 
identical or different from the other reality. So, the main premise of the Buddhist reasoning directed against the Pudgalavādins is established. Thus, the pudgala as ineffable can exist only as an idea, a conventional unit (prajñaptisat) of the language of description.

In addition, Kamalaśîla says, if the opponents claim that the pudgala is ineffable, they thereby clearly state that it is different from the skandhas. Sāntarakșita further says that the presence of opposite properties leads to the distinction of things, such as the rūpa-skandha and the vedana-skandha, the first of which is endowed with material form (mūrtatva), and the other one is deprived of it, and asks: is there no such a difference between the pudgala and the skandhas? the pudgala and the skandhas have such contradictory properties as effability and ineffability. In particular, with regard to the skandhas, we can say that they are not eternal, while about the pudgala we cannot say this. Therefore, by the nature of things, they must be considered as different, Kamalaśîla comments.

The statement that "all sampsāras are not eternal, demonstrates that the rūpa-skandha and the like can very well be called ineffable, while the pudgala cannot be said to be non-eternal because it is completely ineffable in respect of anything. Kamalaśila says that the argument of the Buddhists is conclusive, because the idea of difference is based on the fact of contradictory properties, if it were not so, then the whole universe would be the one single thing that would mean that all things can arise and be destroyed simultaneously.

The pudgala is not a real thing, not only on the grounds that it is ineffable in relation to the skandhas, as explained earlier, but also because it is ineffable with regard to noneternality, concludes Kamalaśīla.

The ability to act effectively (artharkiya) is the distinctive property (lakșana) of being a reality, and this ability belongs only to the momentary (kșanika) things ${ }^{7}$, therefore, if anything is ineffable with regard to momentariness, it cannot be a real thing. All realities are inextricably connected with momentariness, since no effective action is possible for an eternal thing whose activities can be neither successive nor simultaneous. Therefore, if the pudgala is ineffable with regard to momentariness, the pudgala has no nature of reality (vastutā), because a broader property of "being momentary" is absent in it, just as the absence of the property of "being a tree" excludes in the object the property of "being a śinśapā tree".

The opponents may object that if the pudgala were eternal, then effective action would not be compatible with it, which could be neither coherent nor simultaneous ${ }^{8}$. However, it is inexpressible both in respect of eternity and non-eternity.

Kamalaśîla responds that it is impossible to say so, because there cannot be a thing that is deprived of both

\footnotetext{
Dharmas.

According to the logic of Buddhism, the eternal entity can produce only all actions simultaneously, which leads to absurdity but it also by its very definition cannot produce successive actions.
}

properties - eternality and non-eternality, because eternality and non-eternality are mutually exclusive concepts, so the absence of one of these properties necessarily entails the presence of the other.

At the same time, the Buddhists do not object to the use of the term "ineffable" in relation to the pudgala, as the use of names depends entirely on the speaker and therefore cannot be refuted by anyone. The only thing they are trying to do is to find out whether the category "reality" is applicable to the pudgala, is such a nature always present in the pudgala, or not? If it is present, then the pudgala must be called eternal, for eternity consists in nothing else than in the fact that the property always exists and is never destroyed. This was expressed in the words "the learned men call eternal a thing which being is not being destroyed."

If, on the contrary, opponents adhere to another point of view, that the mentioned nature is not always present in the pudgala, then it must be non-eternal, because the only characteristic of a non-eternal thing is that it does not continue, is not permanent.

Therefore, since there are no other alternatives for things other than being non-momentary (eternal) or momentary (non-eternal), and effective activity which can be either successive or simultaneous is incompatible with nonmomentary (eternal) things, the existence of a thing must always be accompanied by momentariness. However, if it is absent in the pudgala, then the property of "existence" should be absent in it. So, it is proved that the pudgala does not exist.

\section{THE PUdGALA IN THE BUdDHIST SCRIPTURE AND ITS REFUTATION}

Further, the opponents ask the question, if the pudgala would not exist at all, why, when the Bhagavat (the Buddha) was asked whether soul (jīva) is one, and body (śarīra) is the other, and whether they are different from each other, he answered that this question belongs to the category of "inexplicable" (avyākṛta), but he did not say directly that soul does not exist. Śāntarakșita responds that the great people (mahātmās) have already explained all the contradictions between the Buddhist Scripture and the real state of things. In fact, this Buddha's teaching was aimed at the refutation of the point of view about the non-existence of ātman, annihilationism (nāstikya).

If the pudgala were really an existing object (dharmin), then it would have been described by the Buddha as either identical or different from the skandhas like all other things, while even the fact that it is an object is not proven. How, then, can we talk about its properties? Thus, an absolutely non-existent object, such as the "hare's horns," cannot have any properties, for example, sharpness, that could be explained. Therefore, instead of saying that the pudgala has only an imaginary existence, the Buddha said that it belongs to the category of the inexpressible.

The Buddha did not say directly that the pudgala does not exist, because the question did not concern the nature of the object itself, but was formulated differently: "Is the pudgala different from body?" 
Or it may be that although the pudgala only exists on the ontological level of the concept, the Buddha wanted to avoid the extreme view that it does not exist, because his disciples were not yet ready to accept the doctrine of the voidness of everything (śūnyatā) . So, Vasubandhu in "Pudgalaviniścaya" said: "Watch out not to be torn by fangs of points of view and not to fall in the [abyss] of deeds! Buddhas teach the Dharma just as a tigress carries her cubs "(in our translation). Thus, Vasubandhu and other teachers explained the real influence of various teachings in such works as "Abhidharmakośa" and "Paramārthasaptati"10.

Opponents raise the question, why then in the Buddhist Scripture there are places where the existence of a "being" (sattva, the same as ātman) is affirmed? Śāntarakșita answers that such statements were made to refute nihilism (nāstika), the view that attman does not exist at all. The statements about the existence of the being are completely compatible with the Buddhist teachings. By the "being" is meant the flow of the ongoing mental skandhas (cittasāntāna), where the idea (prajñapti) of the "being" arises. Therefore, the Bhagavat said: "the being is" (asti sattva). If the Buddha would have taught otherwise, then the listeners would have had the idea that even those impressions (samskāra) that have a permanent character and between which there is no interruption do not exist in the cause of the sequence of moments (kāraṇakșaṇaparampara). This would lead to nihilism, the teaching that the other world (paraloka) and the soul do not exist.

Then the Pudgalavādins put forward a new argument. Why did the Buddha said this: "O monks, I describe to you the burden, taking the burden, dropping the burden and the bearer of the burden"? The term "burden" means the five skandhas, in relation to which attachment is formed, "taking of a burden" is thirst (tṛ̣nāa), discarding the burden is liberation (mokșa), and bearer of the burden is pudgala" (in our translation). (Samyutta-nikāya, 3.22). How can you explain these completely transparent words of the Buddha? After all, the "bearer of the burden" obviously cannot be the same as the burden, the Pudgalavādins insist.

Kamalaśîla replies that when the skandhas are said collectively as simultaneously existing, they are called the aggregate (samudāya), when as existing in the cause-andeffect connection then the sequence (santāna), and when they are viewed as a single concept, they are called the aggregate of the sequence. Thus, the conventional term "pudgala" is applied merely to the skandhas, the aggregate and the sequence. For this reason, the Bhagavat described the pudgala so: "What is the pudgala, the bearer of the burden? It is he who has such and such a name, belongs to such a caste (jāti), to such a clan (gotra), eats such and such food, experiences such and such satisfaction (sukha) and dissatisfaction (duhkha), and lives so much time" (in our translation).

\footnotetext{
9 The main teaching of Madhyamaka, according to which all phenomena (dharmas) are "empty." For more on Śunyavāda, see: [23].

10 The work of Vasubandhu, wholly devoted to criticizing the teachings of the Sāmkhya. Most likely, it is a refutation of the work "Sāṃkyasaptati." of İ́svarakṛṣna, The Sanskrit original is lost. Qv: [24].
}

\section{The PUdGala EXISTS ONLY AS A UNIT OF THE LANGUAGE DESCRIPTION}

Thus, being by nature a collection of the skandhas, the pudgala must be understood as existing only at the level of the concept (prajñaptisat), and not as an eternal substance (nityadravyat), as other philosophical schools of India maintain. It is for this purpose that the Bhagavat used the words mentioned above. Otherwise, if the burden, etc. were considered as distinct from the skandhas, they, like the pudgala, should not be included in the skandhas. Obviously, in the passage above the preceding skandhas in the stream are called the "burden", and the "bearer of the burden" is those that arise as a consequence of the previous skandhas. Thus, the passage quoted does not support the arguments of the opponents.

\section{THE ARGUMENT OF UDYOTAKARA}

Uddyotakara ${ }^{11}$ adduced the following argument: "Those who do not recognize the âtman cannot understand the words of the Buddha who said: "O blessed one, I am not the rūpa, I am not the vedana, I am not the samjuñā, the samskāra or the vijñāna, o blessed one, so are you, o monk, not the rūpa, not the vedana, the saṃjñā, not the saṃskāra and not the vijñāna, o monk." (in our translation). Here it is denied that the rūpa and the other skandhas are the object of the consciousness of the "self" (ahaṃkāra). This negation is particular (viśeșa) and not common (sāmānya), while the one who denies the ātman denies the common and should have said "there is no you." A particular negation always implies some particular statement, for example, when it is said "I do not see with my left eye," it means that I see with my right eye. Similarly, when the quotation in question says "rūpa is not the âtman, vijñāna is not the âtman," it is understood that the attman actually exists, and it is different from the rūpa, the vijñāna, etc. The ātman can be inexpressible or somehow different, but in any case, it exists."

As for the particular negation in this passage, Śāntarakșita replies that this denial was done to protect the disciples from the point of view that the atman is identical with rūpa, vedana, etc., while the Buddha had no intention of asserting anything positively. Otherwise, by asserting something that might damage the listeners, the Buddha would act unreasonably.

\section{CONCLUSION}

In the section of "Ātmaparīkșā" which is dedicated to the discussion with the Pudgalavādins, Śāntarakșita and his commentator Kamalaśîla try to refute the doctrine of the pudgala in the "heretical" school of Buddhism of Vātsīputrīya.

From the text, we can conclude that during the time of Śāntarakșita the Vātsīputrīyas were openly considered nonBuddhists, because under the teachings of the pudgala they actually, in the opinion of the other Buddhists, conducted the

11 One of the most famous representatives of the philosophical school of Nyāya, lived in the 1st half of the 7th century. The author of "Nyāya-vārttika" ("Explanation of the Nyāya-sūtras"). 
doctrine of the ātman, while the doctrine of the anātman was the key Buddhist doctrine from the era of the Buddha.

In the exposition of Kamalaśîla, the pudgala has the following properties: it is the actor of karma, the enjoyer of its fruits, the subject of rebirth and experience, and is identical with the Brahmanist concept of atman, that is, it can be compared with the European concept of "subject". In addition, it is ineffable in relation to identity with the skandhas and eternality or non-eternality.

In the opinion of the "orthodox" Buddhists, the pudgala doctrine in Pudgalavāda is full of contradictions, which Śāntarakșita and Kamalaśîla are trying to reveal and clarify. The main contradiction is logical. The "orthodox" Buddhists adhere to binary logic, that is, the law of excluded middle and the law of contradiction. Therefore, from their point of view, one cannot deny that the pudgala can be either eternal, or non-eternal, either identical with the skandhas, or different from them. Sāntarakșita and Kamalaśíla do not forbid the Vătsīputrīyas to call the pudgala inexpressible, because everyone is free to speak as he wants, they are only trying to find out how real it is. The binary logic of the Buddhists, as well as certain doctrinal statements (such as that all real things are momentary) leads to the fact that Sāntarakșita denies the real existence of the pudgala at all and suggests that it should be viewed as a conventional term, a unit of the language of description. Because of this, it turns out that it cannot have any properties, such as being a subject of experience, rebirth, and so on.

We can state that the "orthodox" Buddhists and the Pudgalavādins adhere to diametrically opposite philosophical logics (the logic of the Vātsīputrīyas is non-binary), so they could never come to an agreement. Moreover, if the opponents of the "orthodox" Buddhists renounced their specific logic, they would fall into the heresy of either "eternalism" (the doctrine of the eternal attman) or annihilationism (the doctrine of the absence of the atman and the other world, the world of rebirth). Sāntarakșita and Kamalaśîla repeatedly emphasize that the true teaching of the Buddha consisted in this middle way between the two extremes, and his various statements were only a way of expounding the teachings by "skillful means" (upāya kauśalya). In this case, the authors of the text actually fall into annihilationism, saying that ātman does not exist in reality, but everything is actually empty.

The argumentation of the authors of the text is also not without contradictions. In particular, Kamalaśîla says that if the pudgala is always of the nature of a reality, then it is eternal. At the same time, Buddhists themselves consider dharmas to be truly real elements of being, which at the same time are not eternal, but momentary.

\section{REFERENCES}

[1] V.P. Androsov Śāntarakṣita // Philosophy of Buddhism: Encyclopedia / Stepanyants M.T. (ed.). Vostoschnaya literatura, Moscow, 2011, 1050 p. (in Russ.), pp. 799-800.
[2] V. G. Lysenko, N.A. Kanaeva, Śāntarakșita and Kamalaśîla on the instruments of valid cognition. M.: Institute of Philosophy RAS, 2014, $295 \mathrm{p}$.

[3] J. Blumenthal, Sāntaraksita, Rgyal-tshab Dar-ma-rin-chen. The ornament of the middle way: a study of the Madhyamaka thought of Śāntarakșita : including translations of Śāntarakșita's Mādhyamakālaṃkāra (The ornament of the middle way) and Gyeltsab's dbU ma rgyan gyi brjed byang (Remembering "The ornament of the middle way"). - Snow Lion Publications, 2004, 381 p.

[4] V. P. Androsov, Madhyamaka // Philosophy of Buddhism: Encyclopedia / Stepanyants M.T. (ed.), Vostoschnaya literatura, Moscow, 2011, 1050 p., pp. 420-422.

[5] A.N. Ignatovich, Madhyamaka // Philosophy of Buddhism: Encyclopedia / Stepanyants M.T., Ed. Vostoschnaya literatura, Moscow, 2011, 1050 p., pp. 422-425.

[6] S.Ju. Lepekhov The Philosophy of the Mādhyamikas and the Genesis of the Buddhist Civilization. Ulan-Ude: Izd-vo BNTs SO RAN, 1999, $237 \mathrm{p}$.

[7] A.K. Chatterjee, The Yogācāra Idealism / Tr. D. Ust'iantsev. Shechen: 2004, 268 p.

[8] D. Messent, The Yogācāra-Svātantrika-Madhyamaka School of Buddhism and Its Influence on Rnying Ma Doctrine with Special Reference to Śāntarakșita's Madhyamakālaṃkāra. University of Bristol, 2003.

[9] Śāntarakșita. Tattvasamgraha, with the comment. Pañjikā of Śrī Kamalaśīla // Gaekwad`s Oriental series / Ed. E. Kṛ̣ṇāmāeārya. With a Foreword by B. Bhattacharyya. Baroda. In 2 vols.

[10] Tattvasaṃgraha of Ācārya Śāntarakșita with the commentary Pañjikā of Śrī Kamalaśîla. Critical Edited by Swāmi Dvārikādas Śāstrī. In two vols. Bauddha Bharati, Varanasi, 1968.

[11] Jha G. (Tr.). The Tattvasangraha of Shantaraksita With the Commentary of Kamalashila . Vol. 1, Delhi: Motilal Banarsidass, 1986, 739 p., p. 159.

[12] Ratié, Une critique bouddhique du Soi selon la Mīmāṃsā: Présentation, édition critique et traduction de la Mīmāmsakaparikalpitātmaparīkșā de Śāntarakșita. Series: Beiträge zur Kultur- und Geistesgeschichte Asiens. Austrian Academy of Sciences Press, 2014. 371 p.

[13] L. I. Titlin, The Polemics with the Nyaya-Vaisheshikas on the Question of the Existence of Self in the "Tattvasamgraha" of Sāntarakșita // E-journal Filosofskaia mysl'. - URL: http://enotabene.ru/fr/article_20948.html (accessed 10.10.2017), pp. 139-163.

[14] L. I. Titlin, The Polemics of Śantarakṣita and Kamalaśīla With the Mìmāmsakas on The Existence and Properties of Atman in "Tattvasamgrahapañjikā" (Translation of an Excerpt) // Gumanitarii: aktual'nye problemy gumanitarnoi nauki i obrazovaniya. - Saransk, Publishing Center of the Historical Sociological Institute of the Mordovia State Univeersity named after N. P. Ogarev, 2018.

[15] L. I. Titlin The Concept of the Self in Sāmkhya and the Polemiscs Between the Buddhists and the Sāmkhyas in the Section "Ātmaparīksāā" of "Tattvasamgraha" of Śānatarakșita on the Existence and Properties of Ātman // Values and Senses, No. 2, 2018.

[16] L. I. Titlin, The Discussion Between the Buddhists and the Sāmkhyas on the Ātman (Translation of an Excerpt from the "Tattvasaṃgrahapañjikā") // Humanities : Contemporary Issues of Humanity and Education, No. 2, 2018.

[17] A. Bareau, The Buddhist Sects of the Lesser Vehicle. Translated from the French by Gelongma Migme Chodron, 2005. URL: http://www.gampoabbey.org/translations2/ani-migme/Bareau-SectesBouddhiques\%20.pdf p. 110.

[18] Priestley L.C.D.C. Pudgalavāda Buddhism: The Reality of the Indeterminate Self. Toronto: Centre for South Asian Studies, University of Toronto, 1999, $255 \mathrm{p}$.

[19] L.I. Titlin, The Notion of the Self in Pudgalavāda Buddhism // Istoriya filosofii № 17. M. : Izd-vo IF RAN, 2013, pp. 15-40.

[20] L.I. Titlin, The Concept of Pugdala in the Buddhist School of Pudgalavāda: the Problem of Interpretation and the Evolution of the Conception. // Vestnik of Russian Peoples' Friendhip University. Series "Philosophy" 2014, No. 1, pp. 105-111. 
[21] V.G. Lysenko, Pudgala // Philosophy of Buddhism: Encyclopedia / Stepanyants M.T., Ed. Vostoschnaya literatura, Moscow, 2011, 1050 p., pp. 566-567.

[22] V.K. Shokhin, Vātsīputrīya // Philosophy of Buddhism: Encyclopedia / Stepanyants M.T., Ed. Vostoschnaya literatura, Moscow, 2011, 1050 p., pp. 208-210.

[23] S. Yu. Lepekhov, Śunyavāda // Philosophy of Buddhism: Encyclopedia / Stepanyants M.T., Ed. Vostoschnaya literatura, Moscow, 2011, 1050 p., pp. 809-811.

[24] A.K. Chatterjee The Yogācāra Idealism / Tr. D. Ust'iantsev, Shechen: 2004,268 p. 